\title{
Estimation of Genetic Parameters and Influence of Non Genetic Factors on Wool Yields in German Angora Rabbits
}

\author{
Loopamudra Sarma ${ }^{*}$, Sanjeet Katoch, Yash Pal Thakur and Varun Sankhyan \\ Department of Animal Breeding, Genetics and Biostatistics, Dr. G.C.Negi College of \\ Veterinary and Animal Sciences, CSKHPKV, Palampur-176062 (H.P), India \\ *Corresponding author
}

\section{Keywords}

German Angora, Genetic parameter, Season,

Wool yield, Year

\section{Article Info}

Accepted:

26 July 2020

Available Online:

10 August 2020

\begin{abstract}
A B S T R A C T
This study was conducted to evaluate the phenotypic profiles, genetic and non-genetic effects on wool production traits in 588 German Angora rabbits maintained at Angora Rabbit Breeding Farm, Kandwari (Himachal Pradesh) from 2000 to 2007. The data were analysed by Harvey's least-squares method of fitting constants. The overall least squares means were $58.77 \pm 35.10 \mathrm{~g}, 169.77 \pm 30.38 \mathrm{~g}, 181.00 \pm 21.30 \mathrm{~g}, 184.73 \pm 23.49 \mathrm{~g}$ and $594.22 \pm 67.13 \mathrm{~g}$ for wool yield at first, second, third, fourth clip and annual wool yield, respectively. Year and season of birth significantly affected wool yield at first, third, fourth clip and annual wool yield; however, wool yield at second clip was significantly affected only by year of birth. The heritability estimates for wool yield at different clips and annual wool yield were low to moderate. Hence, improvement of these traits can be attained through better managemental practices, since there is little scope for genetic improvement of the traits through selection. The genetic, phenotypic and environmental correlations among the wool production traits were low to high in magnitude and positive in direction, which indicate that there is possibility of simultaneous improvement of the wool traits.
\end{abstract}

\section{Introduction}

Wool yield is the most important economic trait for determining the economics of breeding Angora rabbits and appears to be affected by a number of genetic as well as non-genetic factors (Thebault et al., 1992; Katoch et al., 1999 and Allain et al., 2004).

German Angora is the largest variety of Angora rabbits with high prolificacy and higher wool production. They yield very fine quality wool (10-15 micron for undercoat fibres) which is used alone or blended with Merino wool to make quality apparels (Gupta et al., 1995). The yield significantly increases from first shearing onward till the animal attains mature body size usually by 9-12 months of age that is the time of third or fourth clip. The initial wool clips are considered important in early selection of rabbits due to their high genetic correlation with annual wool yield (Rafat et al., 2009) and moderate genetic improvement is possible through selection on the basis of initial clips, particularly the first clip due to its high 
heritability (Niranjan et al., 2011). The present study has been envisaged to determine the influence of genetic and non-genetic factors on wool production traits in German Angora rabbits under sub-temperate Indian conditions to augment the breeding and selection programme.

\section{Materials and Methods}

\section{Data collection and location}

Data pertaining to first, second, third and fourth clip as well as annual wool yield of German Angora rabbits of either sex where, $n$ $=588$, male $=338$ and female $=250$, over a period of 8 years (2000 to 2007), maintained at Angora Rabbit Breeding Farm, Kandwari, Palampur, Distt. Kangra (Himachal Pradesh), under Department of Animal Husbandry (H.P), which is located at a distance of $8 \mathrm{~km}$ from Palampur were utilized in the present study. The data pertained to progenies obtained during subsequent generations of a foundation stock ( 8 bucks and 32 does) of an improved strain of German Angora rabbit imported from Germany in 1994 for replacing the existing stock at that farm. This farm is located in sub-temperate mid-hill region of Himachal Pradesh at an altitude of 1300 meters above the mean sea level at $32^{\circ} 6^{\prime}$ North latitude and $76^{\circ} 32^{\prime}$ East longitude. The average maximum and minimum temperature of the location remains $28.4^{\circ} \mathrm{C}$ in summers (May-June) and $7.2^{\circ} \mathrm{C}$ in winters (usually in January) with $50-70 \%$ relative humidity. The rainfall was recorded more during the end of June due to pre monsoon rains. The entire data were classified into eight years of wool production i.e. from 2000 to 2007, where each year further sub-divided into four seasons viz., winter (November-February), spring (MarchApril), summer (May-August) and autumn (September-October) depending upon the local agro-climatic conditions, and two (male and female) sexes.

\section{Management practices}

All the animals were maintained under uniform housing and management conditions throughout the experiment period. The adult animals were housed in individual flat deck standard-sized wire mesh cages fitted with the wall of the house with top entry and provided feeding and watering fixtures in the front sides. For breeding stock and nurseries, nest box (made up of wooden material) of $36 \times 36$ $\times 30$ centimetre is placed in front of the cages 4-5 days prior to kindling. The advantages of this system of housing include entry of fresh air in the house and easy shifting of the hutch as per the climatic conditions, which is very necessary in that particular climate. For breeding does, the size of the cage was $60 \times$ $60 \times 40$ centimetre and floor was $250 \times 125$ centimetre. Apart from feeding of available seasonal green forages viz., oats in winter and, maize and soya bean in summer season to meet approximately $20 \%$ of the nutritional requirements, the adult animals (above 6 months of age) were offered pelleted concentrate feed @ 175 gm/doe/day and each lactating doe was offered @ 275gm/doe/day of pelleted feed. The concentrate feed pellets contained $15-17 \%$ crude protein, $8 \%$ crude fibre, $0.4-0.6 \%$ methionine and cystine, 12$14 \%$ crude fat, $2-3 \%$ ether extract, $0.6 \%$ arginine, $1 \%$ lysine as well as vitamins and minerals. The water was offered ad libitum. Animals were used for breeding only after full growth i.e. normally at around 8 months of age and the ratio of male and female was 1:5. Selective breeding was practised to create the next generation. Regarding shearing, hand shearing was done four times in a year at three months interval. Respective ages at first, second, third and fourth clip were 2 months, 5 months, 8 months and 11 months. Immediately after shearing, the quantity of wool clips were stored in polythene bags for short term storage which was further kept in galvanized iron boxes. The wool was sold to 
Himachal Pradesh Wool Federation. The rabbits were kept under strict surveillance for all possible health care; culling and medication of affected animals were done whenever needed.

\section{Statistical methods}

The data were analyzed at Department of Animal Breeding, Genetics and Biostatistics, Dr. G.C. Negi College of Veterinary and Animal Sciences, Palampur (H.P) using leastsquares method of fitting constants (Harvey, 1990) with different fixed and regression effects. The statistical model 1 used to analyze the data was -

$\mathrm{Y}_{\mathrm{ijkl}}=\mu+\mathrm{P}_{\mathrm{i}}+\mathrm{S}_{\mathrm{j}}+\mathrm{SX}_{\mathrm{k}}+\mathrm{A}_{\mathrm{ijkl}}+\mathrm{e}_{\mathrm{ijkl}}$

(model 1)

Where, $Y_{\mathrm{ijkl}}=$ the observation on $1^{\text {th }}$ individual of the $\mathrm{k}^{\text {th }}$ sex, which was born in $\mathrm{j}^{\text {th }}$ season of $\mathrm{i}^{\text {th }}$ year,

$\mu=$ overall population mean,

$P_{i}=$ the effect of $i^{\text {th }}$ year of birth,

$S_{j}=$ the effect of $j^{\text {th }}$ season of birth,

$\mathrm{SX}_{\mathrm{k}}=$ the effect of $\mathrm{k}^{\text {th }}$ sex of individual,

$\mathrm{A}_{\mathrm{ijkl}}=$ the partial regression on weight at first shearing and

$\mathrm{e}_{\mathrm{ijkl}}=$ the random error attached to each observation.

Duncan's Multiple Range Test (DMRT) was done to make pair wise comparison among the least squares means wherever significant differences exist by using the modified method of Kramer (1957).

To estimate heritability $\left(\mathrm{h}^{2}\right)$, the model 2 (Hazel and Terril, 1945) was used -

$\mathrm{Y}_{\mathrm{ij}}=\mu+\mathrm{S}_{\mathrm{i}}+\mathrm{e}_{\mathrm{ij}}($ model 2$)$

Where, $\mu=$ overall population mean, $\mathrm{i}=1,2, \ldots . ., \mathrm{s}$ ( $\mathrm{s}=$ number of sires $)$,

$\mathrm{j}=1,2, \ldots, \mathrm{n}_{\mathrm{i}}\left(\mathrm{n}_{\mathrm{i}}=\right.$ number of observations for the sire),
$\mathrm{Y}_{\mathrm{ij}}=$ observations under $\mathrm{j}^{\text {th }}$ progeny belonging to $\mathrm{i}^{\text {th }}$ sire,

$\mathrm{S}_{\mathrm{i}}=$ effect of $\mathrm{i}^{\text {th }}$ sire and

$\mathrm{e}_{\mathrm{ij}}=$ the random error attached to each observation.

The estimates of heritability $\left(\mathrm{h}^{2}\right)$, phenotypic $\left(\mathrm{r}_{\mathrm{P}}\right)$ and genetic $\left(\mathrm{r}_{\mathrm{G}}\right)$ correlations were calculated from the sire component of variance and covariance. The standard errors of heritability were estimated by the method described by Swiger et al., (1964), while the standard errors of phenotypic and genetic correlation were estimated as per the methods of Panse and Sukhatme (1969), and Robertson (1959), respectively.

\section{Results and Discussion}

The estimates of least-squares means (LSM) and standard errors (SE) for wool yield at first, second, third and fourth clip as well as annual wool yield along with the results of DMRT are presented in Table 1. Furthermore, least-squares analyses of variance showing the effect of different factors on the traits are presented in Table 2.

\section{Wool yield at different clips}

The overall LSM \pm SE for wool yield at first clip was estimated to be $58.77 \pm 35.10 \mathrm{~g}$ with a coefficient of variation of $51.97 \%$ (Table 1). The wool yield at subsequent clips $\left(2^{\text {nd }}, 3^{\text {rd }}\right.$ and $4^{\text {th }}$ clip) were higher than the first clip (Table 1) increasing sharply by second clip $(169.77 \pm 30.38 \mathrm{~g}$ with a coefficient of variation of $15.49 \%$ ), third clip (181.00 \pm $21.30 \mathrm{~g}$ with a coefficient of variation of $11.11 \%$ ) and attaining the peak yield by fourth clip $(184.73 \pm 23.49 \mathrm{~g}$ with a coefficient of variation of $11.56 \%$ ). The lower wool yield at first clip was because of the lesser number of wool follicles per unit area which subsequently increased with maturity, wool shedding due to harsh climatic 
conditions, low availability of fodder etc. The mean values for the traits are in accordance with the findings of Swain et al., (1998) in German Angora and Rafat et al., (2009) in adult Angora rabbits. However, lower estimates than the present finding for wool yield at different clips were reported by Bhasin et al., (1998) in different strains of Angora rabbit. On the other hand, Zhou et al., (1988) reported much higher estimates for the traits in Tanghang Angora rabbits.

Table.1 LSM \pm SE along with the results of DMRT for wool yield at different clips and annual wool yield

\begin{tabular}{|c|c|c|c|c|c|c|}
\hline \multirow[t]{2}{*}{ Effect } & \multirow[t]{2}{*}{$\mathbf{N}$} & \multicolumn{5}{|c|}{ Wool yield (g) during different clips and annual wool yield } \\
\hline & & $1^{\text {st }}$ clip & $2^{\text {nd }}$ clip & $3^{\text {rd }}$ clip & $4^{\text {th }}$ clip & Annual yield \\
\hline $\begin{array}{c}\text { Overall Mean } \\
(\mu)\end{array}$ & 588 & $58.77 \pm 35.10$ & $169.77 \pm 30.38$ & $181.00 \pm 21.30$ & $184.73 \pm 23.49$ & $594.22 \pm 67.13$ \\
\hline CV $(\%)$ & & 51.97 & 19 & 11.11 & U & 10.12 \\
\hline \multicolumn{7}{|l|}{ Year of birth } \\
\hline 2000 & 118 & $.65 \pm 3.03^{c}$ & 169.24 & 176.68 & $191.25 \pm 2.12^{\mathrm{d}}$ & $616.68 \pm 5.97^{\mathrm{bc}}$ \\
\hline & 106 & $2.98 \pm 3.25^{\mathrm{a}}$ & & & & $602.42 \pm 6.40^{\mathrm{b}}$ \\
\hline 20 & 53 & $57.48 \pm 4.30^{\mathrm{b}}$ & 197.4 & 190.9 & $190.64 \pm 3.01^{\mathrm{d}}$ & $635.62 \pm 8.48^{\mathrm{c}}$ \\
\hline 20 & 33 & $68.33 \pm 5.60^{\mathrm{bc}}$ & $192.52 \pm 4.82^{\mathrm{cd}}$ & $199.29 \pm 3.68^{c}$ & $171.26 \pm 3.91^{\mathrm{ab}}$ & $630.97 \pm 11.02^{\mathrm{c}}$ \\
\hline 20 & 65 & $42.35 \pm 3.98^{\mathrm{a}}$ & 155.5 & 185.68 & $182.21 \pm 2.78^{\mathrm{cd}}$ & $566.15 \pm 7.84^{\mathrm{a}}$ \\
\hline 20 & 21 & $61.14 \pm 6.79^{\mathrm{b}}$ & 152. & 181.8 & $173.92 \pm 4.74^{\mathrm{ab}}$ & $571.39 \pm 13.37^{\mathrm{a}}$ \\
\hline 20 & 86 & $68.73 \pm 3.75^{\mathrm{bc}}$ & 153 & 176 & 165. & $563.78 \pm 7.38^{\mathrm{a}}$ \\
\hline 2007 & 105 & a & & & & \\
\hline \multicolumn{7}{|l|}{ Season of birth } \\
\hline Wint & 250 & $68.97 \pm 4.02^{b}$ & $169 .($ & 181.69 & $193.45 \pm 2.81^{\mathrm{c}}$ & $611.92 \pm 7.92^{b}$ \\
\hline $\mathrm{Sp}$ & 106 & $44.36 \pm 4.65^{\mathrm{a}}$ & 162.3 & $168.94 \pm 3.06^{\mathrm{a}}$ & $184.16 \pm 3.25^{b}$ & $560.76 \pm 9.16^{\mathrm{a}}$ \\
\hline Sum & 172 & $49.22 \pm 4.28^{\mathrm{a}}$ & 173. & 181.68 & $177.53 \pm 2.99^{\mathrm{ab}}$ & $580.76 \pm 8.43^{\mathrm{a}}$ \\
\hline Autun & 60 & $56.55 \pm 5.59^{\mathrm{ab}}$ & 170.6 & 185.7 & $168.12 \pm 3.90^{\mathrm{a}}$ & $585.96 \pm 11.00^{\text {ab }}$ \\
\hline \multicolumn{7}{|l|}{ Se } \\
\hline & $33 \varepsilon$ & & & 6 & & 1 \\
\hline en & 250 & 4.05 & $171.86 \pm 3.48$ & $180.39 \pm 2.66$ & $182.57 \pm 2.83$ & $591.10 \pm 7.97$ \\
\hline
\end{tabular}

Means with the same superscripts in a column don't differ significantly $(\mathrm{P}<0.05)$

$\mathrm{N}=$ number of observations

Table.2 Least-squares analyses of variance for wool yield at first, second, third and fourth clip as well as annual wool yield

\begin{tabular}{|c|c|c|c|c|c|c|}
\hline \multirow{2}{*}{$\begin{array}{c}\text { Sources of } \\
\text { variation }\end{array}$} & \multirow[t]{2}{*}{ d.f. } & \multicolumn{5}{|c|}{ Mean squares } \\
\hline & & $\begin{array}{l}\text { Wool yield } \\
\text { at first clip }\end{array}$ & $\begin{array}{l}\text { Wool yield at } \\
\text { second clip }\end{array}$ & $\begin{array}{l}\text { Wool yield at } \\
\text { third clip }\end{array}$ & $\begin{array}{l}\text { Wool yield at } \\
\text { fourth clip }\end{array}$ & $\begin{array}{c}\text { Annual } \\
\text { wool yield }\end{array}$ \\
\hline Year of birth & 7 & $14580.17 * *$ & $3193.88 * *$ & $3193.88 * *$ & $5550.39 * *$ & $55479.34 * *$ \\
\hline Season of birth & 3 & $16481.16^{*}$ & 42364.68 & $42364.68^{*}$ & $10817.41 *$ & $57320.98^{*}$ \\
\hline Sex & 1 & 73.84 & 390.32 & 390.32 & 1618.15 & 20824.65 \\
\hline Error & 575 & 933.18 & 404.04 & 404.04 & 455.95 & 3615.23 \\
\hline
\end{tabular}

** $\mathrm{P}<0.01, * \mathrm{P}<0.05$ 
Table.3 Heritability, genetic, phenotypic and environmental correlations among wool production traits

\begin{tabular}{|c|c|c|c|c|c|}
\hline Traits & $\mathbf{1}^{\text {st }}$ clip & $\mathbf{2}^{\text {nd }}$ clip & $\mathbf{3}^{\text {rd }}$ clip & $\mathbf{4}^{\text {th }}$ clip & Annual yield \\
\hline $\mathbf{1}^{\text {st }}$ clip & $\mathbf{0 . 0 9 0} \pm \mathbf{0 . 0 2 0}$ & $0.002 \pm 0.002$ & $0.103 \pm 0.067$ & $0.036 \pm 0.006$ & $0.593 \pm 0.102$ \\
\hline $\mathbf{2}^{\text {nd }}$ clip & $0.198 \pm 0.026$ & $\mathbf{0 . 2 9 0} \pm \mathbf{0 . 0 1 0}$ & $0.238 \pm 0.003$ & $0.964 \pm 0.014$ & $0.823 \pm 0.127$ \\
\hline $\mathbf{3}^{\text {rd }}$ clip & $0.081 \pm 0.012$ & $0.203 \pm 0.017$ & $\mathbf{0 . 3 1 1} \pm \mathbf{0 . 0 1 8}$ & $0.959 \pm 0.105$ & $0.774 \pm 0.006$ \\
\hline $\mathbf{4}^{\text {th }}$ clip & $0.016 \pm 0.010$ & $0.072 \pm 0.011$ & $0.171 \pm 0.004$ & $\mathbf{0 . 3 1 2} \pm \mathbf{0 . 0 2 1}$ & $0.911 \pm 0.116$ \\
& & $(0.054)$ & & & \\
\hline Annual yield & $0.651 \pm 0.031$ & $0.622 \pm 0.088(-$ & $0.532 \pm 0.073$ & $0.419 \pm 0.035$ & $\mathbf{0 . 2 7 0} \pm \mathbf{0 . 0 1 7}$ \\
& & $0.616)$ & & $(0.410)$ & \\
\hline
\end{tabular}

Figures on the diagonal lines are heritability estimates.

Figures above and below the diagonal are genetic and phenotypic correlations, respectively.

Figures in parenthesis are environmental correlations

Effect of year of birth, season of birth and sex on wool yield at different clips

The analyses of variance revealed significant effect of year of birth $(\mathrm{P}<0.01)$ on wool yield at all clips i.e. from first to fourth clip (Table 2) with an inconsistent trend in wool production over the years attributable largely to variations in management and feeding practices over the years. The wool yield at first clip during eight years ranged between $39.12 \pm 3.39 \mathrm{~g}(2007)$ and $76.65 \pm 3.03 \mathrm{~g}$ (2000); second clip ranged between $152.91 \pm$ $5.84 \mathrm{~g}$ (2005) and $197.41 \pm 3.70 \mathrm{~g}$ (2002); third clip ranged between $171.81 \pm 2.23 \mathrm{~g}$ (2007) and 199.29 $\pm 3.68 \mathrm{~g}$ (2003), and fourth clip ranged between $165.45 \pm 2.62 \mathrm{~g}$ (2006) and $191.25 \pm 2.21 \mathrm{~g}$ (2000). The results are in the line of the reports stated by Gaur et al., (1992) and Thebault et al., (1992) in German Angora and different strains of Angora rabbit. On the contrary, non-significant effect of year of birth on third and fourth clip was observed by Sambher (1992) in German Angora rabbits.

Significant effect $(\mathrm{P}<0.05)$ of season of birth was observed for wool yield at all clips under study except at second clip with generally higher wool production in winter born animals (Table 2). In case of wool yield at first clip, lowest yield (44.36 $\pm 4.65 \mathrm{~g})$ was recorded in spring born animals, while it was the highest $(68.97 \pm 4.02 \mathrm{~g})$ in winter born animals; In case of wool yield at third clip, rabbits born in spring season had the lowest wool yield (168.94 $\pm 3.06 \mathrm{~g})$, whereas, the highest wool yield $(185.79 \pm 3.67 \mathrm{~g})$ was recorded in autumn born animals. The averages for wool yield at fourth clip during the four seasons ranged between $168.12 \pm$ $3.90 \mathrm{~g}$ in autumn and $193.45 \pm 2.81 \mathrm{~g}$ in winter. The differences in wool production due to season of birth may be attributed to changes in feed quality, its intake and other changes in managemental practices. Similar significant seasonal effects on wool yield at different clips have also been reported by Sood et al., (2007) and, Bhatt and Sharma (2009) in German Angora rabbits. The wool yield differed significantly among different seasons with the highest and the lowest during winter and summer, respectively. But certain studies (Gaur, 1989 and Sambher et al., 1999) have reported non-significant effect of season of birth on wool yield at different clips.

The sex of the rabbits did not influence significantly wool yield at any clip in the present study (Table 2). This finding is consistent with the findings of Gupta et al., (1995) and Sambher et al., (1999) in Russian 
and German Angora rabbits, respectively. On the other hand, significant differences due to sex were reported by Gaur et al., (1992) and Niedzwiadek et al., (1992) in different strains of Angora rabbit.

\section{Annual wool yield}

The overall LSM \pm SE for annual wool yield was estimated to be $594.22 \pm 67.13 \mathrm{~g}$ with a coefficient of variation of $10.12 \%$. (Table 1 ). The result is in accordance with the findings of Assad et al., (2017) in German Angora rabbits. However, higher (Singh et al., 2006) and lower estimates (Sood et al., 2007) of annual wool yields were also reported in German Angora rabbits.

\section{Effect of year of birth, season of birth and sex on annual wool yield}

Least-squares analyses of variance revealed that the year of birth significantly affected $(\mathrm{P}<0.01)$ the annual wool yield (Table 2$)$. The first year wool yield was the highest (635.62 $\pm 8.48 \mathrm{~g}$ ) for animals' born in the year 2002 and the lowest $(547.01 \pm 6.68 \mathrm{~g})$ for animals' born in the year 2007. There is decline of annual wool yield over the years after 2002 . This may be due to loss of genetic variation which can be restored by replacement of germplasm through introduction of pure breeding stock from other organized farms or fresh import of German Angora rabbits to this farm to maintain superior genotypes and variability in the farm. Present findings are being corroborated by Sambher et al., (1999) and Sood et al., (2007) in German Angora rabbits. However, non-significant effect of year of birth on annual wool yield was reported by Singh (1987) in Russian, British and crossbred Angora rabbits.

Season of birth exerted significant effect $(\mathrm{P}<0.05)$ on annual wool yield (Table 2$)$. Among seasons, the highest wool yield
$(611.92 \pm 7.92 \mathrm{~g})$ was observed among the animals born during winter and the lowest $(560.76 \pm 9.16 \mathrm{~g})$ for the animals born during spring. Higher wool yield from winter born animals may be due to the high temperature during the period of fibre growth, thereby increasing the flow of nutrients to the wool follicles which influenced the wool growth in these animals.

This finding is in accordance with the findings of Sood et al., (2007), Rafat et al., (2007) and, Bhatt and Sharma (2009) in Angora rabbits. However, Sambher et al., (1999) reported non-significant effect of season of birth on the trait in German Angora rabbits.

Though sex was found to have non-significant effect on annual wool yield in the present study but, the wool yield of females were higher than the males (Table 2). Similar nonsignificant effects of sex on the trait were reported by Sambher et al., (1999) and Assad et al., (2017) in Angora rabbits. In contrast, Sood et al., (2007) reported significant effect of sex on annual wool yield in German Angora rabbits.

\section{Genetic parameters}

The estimates of genetic parameters viz., heritability $\left(\mathrm{h}^{2}\right)$, genetic correlation $\left(\mathrm{r}_{\mathrm{G}}\right)$, phenotypic correlation $\left(\mathrm{r}_{\mathrm{P}}\right)$ and environmental correlation $\left(\mathrm{r}_{\mathrm{E}}\right)$ along with the standard errors among wool yield at different clips and annual wool yield are presented in Table 3 .

\section{Heritability}

The heritability estimates for wool yield at different clips and annual wool yield were estimated to be low to moderate in the present study (Table 3 ). These estimates are mainly governed by non-additive gene action with low additive genetic variance and higher 
environmental effects. Hence, improvement of these traits can be attained through better managemental practices since there is little scope for genetic improvement of the traits through selection. These estimates agree with the estimates of Allain et al., (2004) and Niranjan et al., (2011) in Angora rabbits. However, lower (Caro et al., 1984) and higher estimates (Singh and Jilani, 2006) of heritability for these traits were obtained in different strains of Angora rabbits.

\section{Genetic, phenotypic and environmental correlation}

The genetic, phenotypic and environmental correlations among the wool production traits were low to high in magnitude and positive in direction, which indicate that there is possibility of simultaneous improvement of the wool traits. Wool yield at second clip with fourth clip had the highest genetic correlation (0.964 \pm 0.014$)$. Initial wool clips have been found to be important in early selection due to their high genetic correlation with latter clips (Rafat et al., 2009). The present findings are in consonance with the findings of Singh and Jilani (2006) in German Angora rabbits.

In conclusion this study has revealed the importance of genetic and non-genetic factors for wool production traits in German Angora rabbits. Here, the wool production was the highest in winter and autumn born animals. So, it can be recommended to breed the Angora rabbits in the beginning of autumn and winter season. Low to moderate heritability for wool traits reflects that improvement can only be achieved if selection is accompanied by improved managemental practices at the farm. Pure breeding stock from other organized farms or fresh import of Angora rabbits can be introduced to this farm to maintain superior genotypes and variability in the farm.

\section{Acknowledgements}

The authors acknowledge the support of Angora Rabbit Breeding Farm, Kandwari, Palampur, Distt. Kangra (H.P) and Department of Animal Breeding, Genetics and Biostatistics, Dr. G.C. Negi College of Veterinary and Animal Sciences, Palampur (H.P) to carry out the research work.

\section{References}

Allain, D., Rochambeau, H.D., Thebault, R.G. and Vrillon, J.L. (2004). The inheritance of wool quantity and live weight in the French Angora rabbit. Anim Sci., 68: 441- 447.

Assad, N.I., Khan, N.N., Alam, S. and Chakraborty, D. (2017). Performance of wool type Angora rabbits under temperate conditions of Kashmir (J\&K), India. J. Appl. \& Nat. Sci., 9 (2): 1022-1025.

Bhasin, V., Swain, N., Bhatia, D.R., Bhatt, R.S., Siroho, N.S. and Mahajan, A. (1998). Breeding rabbit for Angora wool production under sub-temperate Himalayan conditions. Annual Report of CSWRI, Awikanagar (Rajasthan), 30-31.

Bhatt, R.S. and Sharma, S.R. (2009). Seasonal production performance of Angora rabbits under sub-temperate Himalayan conditions. Asianaustralas. J. Anim. Sci., 22(3): 416420.

Caro, W., Magofke, J.C., Garcia, X., Garcia, G., Carvajal, S., Gecele, P., Jadrijevic, D. and Bruna, G. (1984). Environmental factors affecting fleece production in Angora rabbits. Investigactiones del Departamento de Produccion Animal, 3: 200-206.

Gaur, D. (1989). Performance appraisal of Angora rabbits and their crosses. Ph.D. thesis, Haryana Agricultural 
University, Hissar, India.

Gaur, D., Chhikara, B.S., Gopikrishna, G. and Dutta, O.P. (1992). Genetic and nongenetic factors affecting litter traits in Angora rabbits. Wool and Woollens of India., 4: 29-39.

Gupta, S.C., Gupta, N. and Jain, A. (1995). Adaptability of Russian Angora Rabbits in semi arid tropics. World Rabbit Sci., 3: 143-146.

Harvey, W.R. (1990). User's guide for LSMLMW Mixed model least squares and Maximum likelihood computer programme, $P C$-2 version, Ohio state University, Columbus, USA.

Hazel, L.N. and Terril, C.E. (1945). Heritability of weaning weight and staple in Raugi Rambouillet lambs. $J$ Anim Sci., 4: 347-358.

Katoch, S., Sambher, V.K., Manuja, N.K., Thakur, Y.P. and Gupta, K. (1999). Studies on genetic and phenotypic parameters for wool production traits in Angora rabbits. Indian J Anim Res., 33: 126-128.

Kramer, C.Y. (1957). Extension of multi range test to group correlated adjusted means. Biometrics., 13: 13.

Niedzwiadek, S., Bielanski, P. and Lorkowska, M. (1992). Genetic progress in the wool utility of L-1 and L-2 Angora rabbits. J Appl Rabbit Res., 15: 1658-1665.

Niranjan, S.K., Sharma, S.R. and Gowane, G.R. (2011). Estimation of genetic parameters for wool traits in Angora rabbit. Asian-australas. J. Anim. Sci., 24: 1335-1340.

Oglakcioglu, N., Celik, P., Bedez, Ute T., Marmarali, A. and Kadoglu, H. (2009). Thermal Comfort Properties of Angora Rabbit/Cotton Fiber Blended Knitted Fabrics. Text Res J., 79 (10): 888-894.

Panse, V.G. and Sukhatme, P.V. (1969). Statistical method for agricultural workers. $2^{\text {nd }}$ edn., Indian Council of
Agricultural Research, New Delhi.

Rafat, S.A., Rochambeau-H-de, Brims M., Thebault, R.G., Deretz, S., Bonnet, M. and Allain, D. (2007). Characteristics of Angora rabbit fibre using optical fibre diameter analyzer. J Anim Sci., 85(11): 3116-3122.

Rafat, S.A., Thebault, R.G., Bonnet, M., Deretz, S., Pena-Arnaud, B., Rochambeau, H-de. and Allain, D. (2009). A note on divergent selection for total fleece weight in adult Angora rabbits: direct response to selection on total fleece weight at first and second harvest. World Rabbit Sci., 17: 39-44.

Robertson, A. (1959). The sampling variance of genetic correlation coefficient. Biometrics., 15: 469-485.

Sambher, V.K. (1992). Genetic and phenotypic studies of some of the economic traits in Angora rabbits in Himachal Pradesh. M.V.Sc. Thesis, Himachal Pradesh Krishi Vishvavidyalaya, Palampur, India.

Sambher, V.K., Katoch, S., Thakur, Y.P., Gupta, K. and Manuja, N. K. (1999). Non-genetic factors affecting annual wool yield in Angora rabbits. Indian Vet J., 76: 63-64.

Schlink, A.C. and Liu, S.M. (2013). Angora rabbits: A potential new industry for Australia. RIRDC Publication No.03/014., RIRDC, Australia.

Singh, R.N. (1987). Performance of Angora rabbits in sub-temperate Himalayan region. Short course on "Advances in rabbit Production", Division of Fur Animal Breeding, CSWRI, Garsa (H P): 158-170.

Singh, C.B. and Jilani, M.H. (2006). Genetic studies on the reproductive and productive traits of German Angora rabbits under temperate condition of Garhwal Himalayas. Indian J. Small Rumin., 12(1): 26-32.

Singh, U., Sharma, S.R., Bhat, R.S., Risam, 
K.S. and Kumar, D. (2006). Effect of shearing intervals on the growth and wool parameters of German Angora rabbits. Indian J Anim Sci., 76: 88-91.

Snedecor, G.W. and Cochran, W.G. (1967). Statistical Methods, Sixth edn. Iowa State University Press, Ames, Iowa. Sood, A., Gupta, K., Risam, K.S., Katoch, S. and Kailla, O.P. (2007). Non-genetic factors affecting wool yield in Angora rabbits. Indian J Anim Res., 12: 233-234.

Swiger, L.A., Harvey, W.R., Everson, D.O. and Gregory, I.C.E. (1964). The variance of intra class correlation involving groups with one observation. Biometrics., 20: 818-826.
Mahajan, A. and Bhasin, V. (1998). Breeding rabbits for Angora wool production under sub-temperate Himalayan conditions. Annual Report of CSWRI, Awikanagar (Rajasthan)., 30-31.

Thebault, R.G., Vrillon, J.L., Allain, D., Fahrat, E. and Rochambeau, H-de. (1992). Effect of non-genetic factors on quantitative and qualitative features of Angora wool production at French farms. J Appl Rabbit Res., 15:15681575.

Zhou, J.L. and Zhang, F.Y. (1988). Tanghang Angora- A new variety of Angora rabbit. J Appl Rabbit Res., 11(2): 82.

Swain, N., Bhatt, R.S., Sharma, S.R.,

\section{How to cite this article:}

Loopamudra Sarma, Sanjeet Katoch, Yash Pal Thakur and Varun Sankhyan. 2020. Estimation of Genetic Parameters and Influence of Non Genetic Factors on Wool Yields in German Angora Rabbits. Int.J.Curr.Microbiol.App.Sci. 9(08): 3799-3807. doi: https://doi.org/10.20546/ijcmas.2020.908.438 